\title{
A csecsemő- és kisgyermeknevelő BA-szak létesítésének előzményei, háttere és tízéves jubileumi konferenciája
}

\author{
DÁVID MÁRIA \\ Eszterházy Károly Egyetem
}

\begin{abstract}
A csecsemö- és kisgyermeknevelö képzés 2009 szeptemberében indult elöször mint a magyar felsőoktatási rendszer BA-szintü alapképzési szakja. A tanulmány áttekinti a szaklétesités szakmai megalapozottságát. Bemutatjuk a szakalapitási dokumentum kidolgozásának és elfogadásának folyamatát, és a szak indulásához kapcsolódó országos szakmai együttmüködést. Bemutatjuk a képzés tízéves évfordulójának alkalmából szervezett jubileumi konferencia eseményeit is.
\end{abstract}

Kulcsszavak: szaklétesités, koragyermekkori nevelés, országos együttmüködés, jubileumi konferencia

\section{A szaklétesítés szakmai indokoltsága}

Hazánkban 1852. április 21-én, Pesten nyitotta meg kapuit az első magyar bölcsőde, (Vokony, 2002) mint a gyermekek családon belüli nevelésének támogatását szolgáló intézmény. Az intézménytípusnak megfelelő szakemberképzés azonban igen nagy késéssel kezdődött. A képzés fejlődésének jelentős állomása volt 1970-ben a Bölcsődék Országos Módszertani Intézetének (BOMI) megalakulása (Vokony, 2002). A BOMI komplex feladatkörébe tartozott a bölcsődék szakmai hálózattá fejlesztése, tudományos kutatásokra alapozott módszertani fejlesztések megvalósítása, a bölcsődei gondozónők képzésének, továbbképzésének szakmai irányítása. A BOMI tevékenysége országosan kihatott a szakterület fejlődésére, megalapozta egy korszerű szemléletű kisgyermeknevelői tevékenységrendszer kialakítását, melynek eredményei jelenleg is meghatározóak a bölcsődei nevelés gyakorlatában.

A bölcsődei ellátás a rendszerváltásig az egészségügyi ellátás keretei között működött. Emiatt dominánsabb volt az egészségügyi szemlélet, hangsúlyosabban jelentek meg a gondozási feladatok a korosztály igényeihez igazodóan, de a kezdetektől jelen voltak a pedagógiai nézetek is a szakmai elképzelésekben, és egyre nagyobb hangsúly tevődött a pedagógiai, pszichológiai aspektusokra (Nyitrai, 2015).

A képzés fejlődése szempontjából kiemelhető Akócsi Sándorné szerepe, aki már 1968ban a Népegészségügyben megjelent írásában felhívja a figyelmet arra, hogy a gondozónőknek az óvónőkkel és a tanítókkal azonos szintü képzésben kellene részesülniük (Nyitrai, 2015) A magasabb szintű szakképzettség irányába mutató törekvések első jelentős állomása azonban csak 1999-ben érkezett el, amikor a csecsemő- és kisgyermeknevelö-gondozó felsőfokú szakképzés elindulhatott. A szakalapítást és szakindítást támogató MAB-határozatot ebben az évben kapta meg a kezdeményező Budapesti Tanítóképző Főiskola. A szakterület jeles képviselői már ekkor jelezték azt, hogy a képzésnek a felsőoktatás szerves részévé kellene válnia, erre azonban csak tíz év múlva, 2008-ban került sor (Podráczky, 2015).

Magyarország köznevelési rendszerét 2009 előtt az jellemezte, hogy felsőoktatási szinten képzett pedagógusok csak a hárómévesnél idősebb gyermekekkel foglalkozhatak. A 0-3 éves korosztály nevelésére, fejlesztésére felkészítő speciális szakmai képzés kimaradt a felsőoktatás pedagógusképzési palettájából. A korai tanulással kapcsolatos pszichológiai kutatások azonban erősen kétségbe vonják ennek az álláspontnak a jogosságát. Amit 
A csecsemő- és kisgyermeknevelő ba-szak létesítésének előzményei...

korábban kizárólag gondozást igénylő életszakasznak gondoltak, arról mára bebizonyosodott, hogy fontos életszakasza az idegrendszeri, a kognitív, és a szociális fejlődésnek, ebből következően a fejlesztésnek is. Már a legkorábbi életkorban is tanul a gyermek, és ezt kívülről is támogatni lehet. Hangsúlyosan nagy jelentőségű ez az életkor a hátrányos helyzetű gyermekek esetében, ahol a családi háttér nem mindig teszi lehetővé a pszichikus funkciók optimális érését, fejlődését, de ez nem csak a szegény, alacsony végzettségü családtagok esetén jelenthet problémát.

Podráczky úgy látja, hogy e terület felértékelődését és hangsúlyossá válását több tényező együttesen eredményezte. Ezek közül három dolgot tart különösen figyelemre méltónak: a gyermekkori agykutatás, a neurobiológiai kutatások vizuálisan is megjeleníthető eredményeit, a leghátrányosabb helyzetű, szegénységben élő családokra irányuló és a támogatásukkal kapcsolatos tudás megsokszorozódását, valamint a - longitudinális vizsgálatokkal is igazolt - tényt, hogy a színvonalas kisgyermekkori ellátásba történő befektetés hatványozottan megtérül (Podráczky, 2015).

Blaskó és munkatársai rámutatnak, hogy a közgazdaságtan sokszorosan bizonyított állítása, hogy a közoktatásban átadott készség és tudás emberi tőkének tekinthető. Ez a tőke hasznot hajt annak is, aki megszerzi, és hasznot hajt a társadalom egészének is, a magasabb adóbevételeken és az alacsonyabb bünözési rátákon keresztül. Újabb eredmények azt is mutatják, hogy ebben a folyamatban a korai szakasznak különösen nagy a szerepe. Longitudinális statisztikai elemzésekkel kimutatható, hogy jelentős egyéni és társadalmi hozama lehet a képzett pedagógusok felügyeletével folyó foglalkozásnak. A „Biztos Kezdet” kutatások a kisgyermekkori ellátás társadalmi hatásait empirikus közgazdaságtani eszközökkel vizsgáló tanulmányai egyöntetüen arra a következtetésre jutnak, hogy ha a gyermekek életük korai éveiben megfelelő neveléshez, fejlesztési lehetőségekhez jutnak, és azt gondos nevelés követ az alap és középfokú oktatásban is, akkor jobb iskolai eredményekhez, jelentős társadalmi és oktatásbeli megtakarításokhoz, magasabb adóbevételekhez vezet. Az idézett tanulmányok szerint ezek a hatások bőven belenyúlnak az iskolaköteles kor, sőt az óvodáskor elé is. A társadalmi haszon különösen nagy, ha hátrányos helyzetű gyermekek jutnak kora gyermekkori nevelési és fejlesztési lehetőségekhez (Blaskó és mtsai, 2009).

Amerikában a 2013. évi elnöki jelentés alapján az iskolai előkészítőkre helyezik most a hangsúlyt. Rájöttek arra, hogy azok a gyermekek, akik ilyen fejlesztésben részesülnek az iskola előtt, jobban teljesítenek iskolai tanulmányaikban. Azt tapasztalták, hogy a korai készségfejlesztés nemcsak az iskolában jelent előnyt, hanem az egyén egész életpályájára hatással van. Az UNESCO 2011ben új ISCED besorolást hozott létre a 3 év alatti fejlesztés, képzés számára. Az emberi tőke minőségi fejlesztésének hangsúlya tehát nemzetközi viszonylatban az iskoláskor előtti képzésre helyeződött át (Petőné, 2016).

A szakalapítási szándék egy sajátos történelmi helyzetben jelentkezett, amikor a magyar felsőoktatás képzési szerkezetének átalakulása, az úgynevezett „bolognai folyamat" zajlott. A hagyományos, duális képzésről (egyetemi vagy főiskolai szintü képzés) a többciklusos képzésre (BA/BSc - MA/ $\mathrm{MSc}-\mathrm{PhD}$ ) való áttérést az indokolta, hogy a magyar felsőoktatás szakszerkezete összhangba kerüljön az európai felsőoktatási térrel. Hazánk 2003-ban kezdett neki a ciklusos képzési szerkezet kidolgozásának, majd bevezetésének, és a felsőoktatási intézmények mindegyike részt vett ebben az átállásban. A képzési programok nagy többségét (17 szak kivételével) átstrukturálták, és a 2006/2007es akadémiai évben már 91 ezer fö vett részt az első ciklushoz tartozó alapképzésben (Derényi, 2010).

Az átállás jogszabályi feltételeit a 289/2005. számú kormányrendelet, majd az új felsőoktatási törvény teremtette meg, amely meghatározta és bevezette az új képzési szerkezetet, és tartalmazta a régi megszüntetésének lépéseit. A törvényhez végrehajtási kormányrendelet is kapcsolódott (79/2006. sz. korm. rend.). A 
képzési programok kereteit a 15/2006. sz. OM miniszteri rendelet tette közzé. Ez a rendelet tartalmazta az alap- és mesterszakok létesítési dokumentumait (Derényi, 2010). Értelemszerűen a csecsemő- és kisgyermeknevelő alapszak létesítési dokumentuma még hiányzott ebből a rendeletből.

A felsőoktatási helyzetkép indokolta azt, hogy az alapképzési rendszer első nagyobb áttekintésének (az első évfolyam kifutásának) idejéig moratórium lépett életbe az új szakok létesítésével kapcsolatban.

\section{A szaklétesítés előkészítő munkálatai - országos összefogás}

A csecsemő- és kisgyermeknevelő alapszak létesítésének szükségessége több szakmai fórumon és főhatósági megbeszélésen felmerült, már 2005ben. Az Eszterházy Károly Főiskola a szakalapítási folyamat első lépéseként az Ifjúsági, Családügyi és Esélyegyenlőségi Minisztérium szakmai támogatását kérte meg, amely minisztérium abban az időben a bölcsődei terület irányító főhatósága volt. 2006. január 4-i keltezésű, Göncz Kinga akkori miniszterasszony szakalapítási kezdeményezésünket támogató levele, melyben kifejti, hogy a kezdeményezés egybeesik a minisztérium hosszú távú terveivel, és azzal teljes mértékben egyetért. Kiemeli, hogy „a 0-3 éves korosztály professzionális ellátására pszichológiai, pedagógiai és társadalmi szempontból egyaránt szükség van. A korai életszakaszban kezdődő szakszerü nevelés pedig a társadalmi esélyegyenlőség növelésének egyik fontos eszköze." (7795-8/2005, Az Ifjúsági, Családügyi, Szociális és Esélyegyenlőségi Miniszter támogató levele, 2006).

E támogató levél megérkezését követően indult el a szaklétesítést előkészítő szakmai munka, mely két vonalon folyt. Részben elindult egy széles körű országos szintű szakmai összefogás a szaklétesítés sikerességéért, másrészt elkezdődött a szaklétesítési kérelem kidolgozása, a szükséges szakalapítási dokumentáció összeállítása. A szaklétesítési kérelem akkreditációra való előkészítése érdekében az Eszterházy Károly Egyetemen munkacsoport alakult, amelynek feladata volt a szakalapítási dokumentáció előkészítése, a kérelem kidolgozása, az új alapszak létjogosultságának szakszerủ indoklása, a képzési és kimeneti követelmények meghatározása. A munkacso- portban Dr. Dávid Mária, a szak későbbi felelőse, Dr. Ludányi Ágnes, a Szociálpedagógia Tanszék vezetője és Dr. Estefánné dr. Varga Magdolna Dékán vettek részt. A munkacsoport mindhárom tagja pszichológus és gyógypedagógus végzettséggel rendelkezik, ezen túlmenően Dávid Mária és Estefánné Varga Magdolna középfokon szerzett „általános asszisztens és csecsemőgondozó" ismeretei is nagyban hozzájárultak a szakalapítás sikeréhez.

Az országos szintű szakmai egyeztetések résztvevői a kora gyermekkori nevelésben érintett felsőoktatási intézmények, a szakhatóságok és az érintett korosztállyal foglalkozó szakmai szervezetek voltak. A közös munka irányítását Dr. Estefánné Dr. Varga Magdolna végezte. A felsőoktatási intézmények konzorciumba tömörültek. 2007. január 10-én tartották az első kibővített konzorciumi értekezletet Egerben.

A konzorcium vezetője az egri Eszterházy Károly Főiskola volt. A konzorcium tagjai pedig a következő felsőoktatási intézmények: Miskolci Egyetem Comenius Tanítóképző Főiskolai Kar, Sárospatak; Pécsi Tudományegyetem Egészségügyi Főiskolai Kar Szombathelyi Képzési Központ, Szombathely; Pécsi Tudományegyetem Illyés Gyula Főiskolai Kar, Szekszárd; Berzsenyi Dániel Főiskola, Szombathely; Széchenyi István Egyetem Petz Lajos Egészségügyi és Szociális Intézet, Győr; Tessedik Sámuel Főiskola Pedagógiai Főiskola Kar, Szarvas; Eötvös József Főiskola Pedagógiai Fakultás, Baja; Kecskeméti Főiskola Tanítóképző Főiskolai Kar, Kecskemét; Nyugat-Magyarországi Egyetem Benedek Elek Pedagógiai Kar, Sopron; Nyíregyházi Főiskola; Eötvös Lóránd Tudományegyetem Tanító- és Óvóképző Főiskolai Kar, Budapest; Szegedi Tudományegyetem Juhász Gyula Pedagógusképző Kar, Szeged.

A konzorciumi értekezleten a résztvevők megbeszélték a szaklétesítés előkészítéséhez kapcsolódó feladatokat, és kinyilvánították a konzorciumban való részvételi szándékukat.

A 2006/2007-es tanév tavaszi szemesztere a szükséges támogató nyilatkozatok összegyűjtésével, és a szaklétesítési dokumentáció előkészítésével telt el.

A főhatóságok közül az Oktatási és Kulturális Minisztérium képviseletében dr. Rádli Katalin támogatta a szaklétesítési folyamatot. A szaklétesítéshez sok írásos nyilatkozatot gyűjtött össze a konzorcium. A Szociális és 
A csecsemő- és kisgyermeknevelő ba-szak létesítésének előzményei...

Munkaügyi Minisztérium, Szociálpolitikai Szakállamtitkára, Forgó Györgyné támogató nyilatkozatában kiemelte, hogy „A 3 éven aluli gyermekek napközbeni ellátásának fejlesztése rendkívüli jelentőséggel bír mind a nők munkába állási esélyeinek fokozása, mind a gyermekek - különös tekintettel a hátrányos helyzetű gyermekekre - szocializálódása szempontjából." (3204-2/2007, SZMM Szociális és Munkaügyi Minisztérium Szociálpolitikai Szakállamtitkára támogató levele).

A Szociálpolitikai és Munkaügyi Intézet Főigazgatója, Dr. Simonyi Ágnes támogató nyilatkozatában úgy fogalmaz, hogy „...évek óta nagy szükség van arra, hogy BA szintű csecsemő- és kisgyermeknevelő szak létesüljön, mivel így érhető el, hogy azokban az intézményekben, amelyek csecsemők és kisgyermekek gondozását, nevelését biztosítják, a munkatársak adekvát, a szakmaterületnek megfelelő képesítést szerezhessenek." (198/2007 RH Szociálpolitikai és Munkaügyi Intézet támogató nyilatkozatai). Rózsa Judit, a Szociálpolitikai és Munkaügyi Intézet Gyermekvédelmi Főosztályának bölcsődei szakreferense is támogató nyilatkozatban állt ki a szaklétesítés mellett. Hangsúlyozta, hogy a bölcsődei gondozónők felsőfokú képzése már másfél évtizede kitűzött célja a szakembereknek, és ráirányította a figyelmet arra, hogy a szakma új elemekkel bővült. Ezek közül kiemelte, hogy hangsúlyosabbá vált a szülőkkel való együttműködés, nagyobb gondot kell fordítani a nevelőpartneri kapcsolat kialakítására, és a szülői szerep támogatására. Azt is új feladatként nevezte meg, hogy a bölcsődék fogadnak sajátos nevelési igényű gyermekeket is, és így a korai fejlesztés megvalósításában is szerepük lehet. Felhívta a figyelmet arra, hogy a képzésnek ezekre az új típusú feladatokra is fel kell készítenie a hallgatókat. Reményét fejezte ki, hogy a képzés magasabb szintre való emelése növeli majd a hivatás társadalmi elismertségét, melynek eredményeként több fiatal választhatja ezt a pályát, és megoldódhat majd az utánpótlás kérdése is (198/2007 RH Szociálpolitikai és Munkaügyi Intézet támogató nyilatkozatai).

A szaklétesítést szakmai szervezetek és intézmények, valamint civil szervezetek is támo- gatták. A Magyar Bölcsődék Egyesülete részéről Acsainé Végvári Katalin aláírásával kaptunk támogató nyilatkozatot, és az elnökasszony szakmai tanácsaival folyamatában végig kísérte a szakalapítás lépéseit. A Bölcsődei Dolgozók Demokratikus Szakszervezete részéről Szűcs Viktória támogatta a szaklétesítést. Nyilatkozatok érkeztek bölcsődéktől, egyesített bölcsődéktől, bölcsődei igazgatóságoktól, módszertani bölcsődéktől, és még több szülői fórum is támogatta a munkát.

A felsőoktatási szakszerkezet átalakítása miatt azonban az alapszakok szerkezetét még nem lehetett módosítani. A bolognai rendszer kialakulását követően az alapszakok szerkezetének megnyitásához szükség volt a Magyar Rektori Konferencia (MRK) állásfoglalására, ezen belül a Magyar Rektori Konferencia Pedagógusképzési Bizottságának támogatására.

Az Eszterházy Károly Főiskola 2007. szeptember 25-én nyújtotta be kérelmét a Magyar Rektori Konferencia Pedagógusképzési Bizottságához a támogatásra (443/2007.TKTK: Az Eszterházy Károly Egyetem Tanárképzési és Tudástechnológiai Karának kérelme a Magyar Rektori Konferencia Pedagógusképzési Bizottságához)

A kérelmet a bizottság háromszor tárgyalta, és csak a 2008. április 26-i ülésén hozott támogató határozatot (Jegyzőkönyv a Magyar Rektori Konferencia Pedagógusképzési Bizottságának 2008. április 26-i üléséről). A Pedagógusképzési Bizottság elnöke Dr. Hauser Zoltán az alábbi levélben kérte a MRK elnökét, hogy a Magyar Felsőoktatási Akkreditációs Bizottság felé az MRK egyetértését kifejező levelét megküldeni szíveskedjen.

„Az MRK PKB 2008. április 26-i ülésén tárgyalta a »csecsemő- és kisgyermeknevelő« alapszak létesítésének tervezetét. A kezdeményezés mintegy két évre tekint vissza, melyet a képzésben érintett szakminisztériumok is támogatnak. Eddig a bizottság azt az álláspontot képviselte, hogy bár tartalmilag és koncepcionálisan egyetért a szándékkal, de várjuk meg az alapképzési rendszer első nagyobb áttekintésének idejét. Tekintettel arra, hogy az alapképzési szakszerkezet áttekintése most bekö- 
vetkezett, a bizottság egyhangú szavazással javasolja és kezdeményezi az alapszak-szerkezetben a pedagógusképzési terület bővítését a csecsemő- és kisgyermeknevelő alapszak létesítésével." (4-4/2008. RH Magyar Rektori Konferencia Pedagógusképzési Bizottsága levele a Magyar Rektori Konferencia elnökéhez).

Ezt követően került sor a szaklétesítési kérelem véglegesítésére 2008. május 15-én, az Eszterházy Károly Egyetem, mint a konzorcium vezetője, pedig május 20-án nyújtotta be a csecsemő- és kisgyermeknevelő alapszak szaklétesítési kérelmét a Magyar Felsőoktatási Akkreditációs Bizottsághoz (2008/7/ XII/3/1. számú MAB határozat, 2008).

\section{A szaklétesítési dokumentum jellemzői}

A szaklétesítési kérelem akkreditációra való előkészítését az Eszterházy Károly Egyetemen létrehozott, fentebb említett munkacsoport végezte.

A szaklétesítést kérelmező felsőoktatási intézmény az Eszterházy Károly Főiskola volt. A szaklétesítési kérelmet Dr. Hauser Zoltán rektor írta alá.

A szaklétesítési dokumentumhoz nyilatkozattal hozzájáruló konzorciumi tagok és akkori rektorok:

Eötvös József Főiskola Pedagógiai Fakultás, Baja, Prof. Dr. Majdán János, rektor

ELTE Tanító- és Óvóképző Főiskolai Kar, Budapest, Dr. Hudecz Ferenc, rektor.

Miskolci Egyetem Comenius Tanítóképző Főiskolai Kar, Prof. Dr. Patkó Gyula rektor.

Nyíregyházi Főiskola, Dr. Jánosi Zoltán, rektor.

Nyugat-Magyarországi Egyetem, Sopron, Prof. Dr. Faragó Sándor, rektor.

Pécsi Tudományegyetem, Illyés Gyula Főiskolai Kar, Szekszárd, Dr. Gábriel Róbert, rektor.

Tessedik Sámuel Főiskola, Szarvas, Dr. Puskás János, rektor.

A szaklétesítésben részt vevő konzorciumi felsőoktatási intézmények szenátusainak a szaklétesítést támogató határozatait csatoltuk a szaklétesítési kérelemhez (Szaklétesitési kérelem, csecsemö- és kisgyermeknevelö alapszak, 2008).

\section{$A z$ új szak föbb jellemzői}

A csecsemő- és kisgyermeknevelő alapképzési szakon szerezhető végzettségi szint: alapfokozat (baccalaureus, bachelor; rövidítve: BA), a szakképzettség oklevélben szereplő megjelölése: csecsemő- és kisgyermeknevelő.

Képzési terület: pedagógusképzés.

A képzési idő: 6 félév, 180 kredit

A „Csecsemő- és kisgyermeknevelő BA” alapképzési szak célja, olyan felsőfokú szakképesítésű szakemberek képzése, akik a feladatkörükön belül a kisgyermek gondozása és fejlesztése érdekében alkalmazzák a pedagógiai nevelési módszereket. Megfelelő elméleti és gyakorlati ismeretek birtokában segítik a célzott korosztály egészséges testi és személyiségfejlődését, szocializációját, és a családok nevelési tevékenységét." (Kérelem, csecsemö- és kisgyermeknevelö alapszak létesitésére, 2008. 12. o.).

A szaklétesítési dokumentum tartalmazza a szak képzési céljának és követelményeinek a rokon szakokkal történő összehasonlítását, illetve a karakterisztikus különbségek (szaktávolság) bemutatását. A csecsemő és kisgyermeknevelő alapszak az óvodapedagógus, tanító képzési ágba tartozik. A szakalapítási anyag szerint az óvodapedagógus és tanító szakoktól 65-70\%-ban tér el, az alábbi indokok miatt:

- „Az eltérés jelentős része a speciális életkorra vonatkozó társadalomismereti, jogi, pedagógiai-pszichológiai ismeretekből adódik.

- Markáns eltérést jelez mind a tanítói, mind az óvodapedagógusi szaktól az ápolási, gondozási, egészségügyi ismeretek jelenléte, amely csak ebben a képzésben jelenik meg.

- Ugyanígy specializált a 30 kreditértékkel bíró szakmai gyakorlat, amely az 0-3 éves korosztály gondozásinevelési-fejlesztési feladataira koncentrál, és ez a többi képzésben nem jelenik meg.

- A szakmai tevékenységek szervezésének módszertanában is jelentős eltérés tapasztalható." (Kérelem, csecsemö- és kisgyermeknevelö alapszak létesitésére, 2008. 9. o.). 
A csecsemő- és kisgyermeknevelő ba-szak létesítésének előzményei...

A szaklétesítési kérelem tartalmazza az új szak képzési és kimeneti követelményeinek meghatározását, amely később majd beemelődik és megjelenik a 15/2006. sz. OM miniszteri rendeletben.

A kérelem mellékletei pedig azok a támogató nyilatkozatok képezik, amelyeket az előkészítő munka során szereztek be a szakalapítók. A mellékletek tartalmazzák a konzorciumban résztvevő felsőoktatási intézmények szenátusi határozatait, és elfogadó nyilatkozatait, az MRK Pedagógusképzési Szakbizottságának támogató nyilatkozatát, az ágazati feladatok ellátását érintő szaktárca véleményét, a kompetens szakmai szervezetek, munkaadók és szülői szervezetek véleményét és a szakmai egyeztetések jegyzőkönyvi kivonatait.

A csecsemő- és kisgyermeknevelő BAképzés különbözik az elődnek tekinthető több különböző névvel illetett felsőfokú szakképzéstől is. Az OKJ-s képzések hagyományos ismeretanyagát megtartva, egészségtudományi alapozást nem feledve, az új szak nagyon jelentős többlet kompetenciát is tartalmaz. Erőteljesebbé vált benne a pszichológiai, pedagógiai, és társadalomismereti alapozás, mintegy előkészítve a tovább lépési lehetőséget a mesterképzésbe.

Erőteljesen megjelenik benne a kora gyermekkori fejlődés tudatos és személyre szabott támogatása, az atipikus fejlődés felismerése, és a kompetenciahatárok ismeretében közreműködés a kora gyermekkori intervencióban, az interdiszciplináris tevékenységekben.

Új elemként jelenik meg benne a szülői szerep támogatására való felkészítés, olyan ismeretek és készségek kialakítása, amelyek az egyéni tanácsadást, és a szülőcsoportos beszélgetések vezetését teszik lehetővé.

A Magyar Felsőoktatási Akkreditációs Bizottság 2008 október 7-én kelt határozata elfogadta a szaklétesítési kérelmet. „A MAB támogatja a csecsemő- és kisgyermeknevelő alapképzési szak létesítését, és a képzési és kimeneti követelmények megjelentetését, a benyújtott, az Eszterházy Károly Főiskola által kidolgozott anyag alapján." (2008/7/XII/3/1. számú MAB határozat). A szaklétesítési dokumentum alapján megjelent a csecsemő és kisgyermeknevelő BA-szak képzési és kimeneti követelménye, amely lehetővé tette az új szak indítását több felsőoktatási intézményben is. A MAB-engedély dátumát tekinthetjük a csecsemő- és kisgyermeknevelő BAszak születésnapjának.

Ezúton szeretnénk köszönetet mondani a szakalapítási folyamatban részt vevő szakemberek kitartó munkájáért.

„Ez a fejlemény a szakma fejlődésének egésze szempontjából meghatározó jelentőségű. Részben azért, mert a felsőoktatás egészében vadonatúj Csecsemő- és kisgyermeknevelő alapszakot a MAB a neveléstudományi területen akkreditálta, részben mert ezzel a lineáris képzési rendszerben lehetővé vált, hogy a legjobban felkészültek az alapszakot követően szakterületük megtartásával folytathassák tanulmányaikat a mesterképzésben (Neveléstudományi mesterszak), azt követően pedig akár a doktori képzésben is." (Podráczky, 2015. 72. o.).

A szakalapítást követően élénk országos szakmai munka kezdődött az új szak fejlesztése, és tartalmi elemeinek kikristályosítása érdekében. ATanító- és Óvóképzők Országos Programfejlesztő Bizottsága - Dr. Podráczky Judit kezdeményezésére 2009. szeptember 17-én megalakult a Csecsemő és kisgyermeknevelő BA-képzés Országos Programfejlesztő Bizottsága, (CsOPB), mint a magyar felsőoktatásban új alapszakként megjelenő képzés szakmai fóruma. Vezetője Dr. Dávid Mária lett, aki a szakalapítási kérelem kidolgozásában is kulcsszerepet töltött be. A CsOPB mint országos szakmai grémium fö feladatának tekintette a "Csecsemő és kisgyermeknevelő" BA-alapképzés, képzésében részt vevő felsőoktatási intézmények munkájának segítését, a szakmai szervezetek és a képző intézmények közötti kooperáció elősegítését, a minőségi tananyagfejlesztés támogatását, az országos szintű együttműködések elősegítését, a szakkal kapcsolatos információk áramoltatását.

Az első évfolyam 2009 szeptemberében kezdhette meg tanulmányait a csecsemő- és kisgyermeknevelő BA-alapszakon. A szaklétesítés sikerét jól mutatja, hogy tíz évvel később, a 2019 decemberében megjelenő 
felsőoktatási felvételi tájékoztatóban más 12 felsőoktatási intézmény 18 képzési helyen hirdette meg a szakot.

Az eltelt 10 év alatt sokan szereztek kisgyermeknevelői diplomát, és sokan már a ráépülő neveléstudományi mesterszakot is elvégezték. E tíz év szakmai fejlődését, annak értékelését kötetünkben Podráczky Judit tanulmánya mutatja be.

Érdemes azonban a jubileum kapcsán arról is szólni, hogy hogyan ünnepelte meg a szakma, és a képző intézmények a tízéves születésnapot.

\section{A csecsemő- és kisgyermeknevelő alapképzési szak létesítésének 10. évfordulója alkalmából rendezett Jubileumi Konferencia}

A csecsemő- és kisgyermeknevelő BA-szak első évfolyamának indítására 2009-ben került sor. A szaklétesítés tízéves évfordulójának ünnepi megemlékezését a Csecsemő- és kisgyermeknevelő képzés Országos Programfejlesztő Bizottsága (CsOPB) kezdeményezte, és a szakalapítás konzorciumvezető felsőoktatási intézménye, az Eszterházy Károly Egyetem adott neki otthont, 2019. november 14-15-én.
A Jubileumi Konferenciát az Emberi Erőforrások Minisztériuma, Család- és ifjúságügyért Felelős Államtitkársága támogatta. A konferencia szervezésében a Magyar Bölcsődék Egyesülete nyújtott segítséget. A támogatásokat ezúton is szeretnénk megköszönni.

A meghívottak köre: az irányító hatóságok képviselői, a csecsemő- és kisgyermeknevelő alapképzést indító felsőoktatási intézmények képviselői, a szakmai szervezetek képviselői, a bölcsődei területen dolgozó módszertani központok képviselői, illetve a területen a gyakorlati képzésben dolgozó szakemberek, mentorok. A tanácskozásra az előkészítő szervezőbizottság kétnapos programot tervezett. A jelentkezéshez elektronikus felületet hoztak létre, amelyen a részvételi szándék jelzése mellett poszterbemutatóra, szekcióelőadásra, és mühelymunka vezetésére lehetett regisztrálni.

A konferencia programja az első napon plenáris előadásokkal kezdődött. A résztvevőket Kovácsné Bárány Ildikó, a bölcsődei ügyek koordinációjáért felelős miniszteri biztosa levélben köszöntötte, majd Dr. Liptai Kálmán, az Eszterházy Károly Egyetem rektora megnyitotta a rendezvényt.

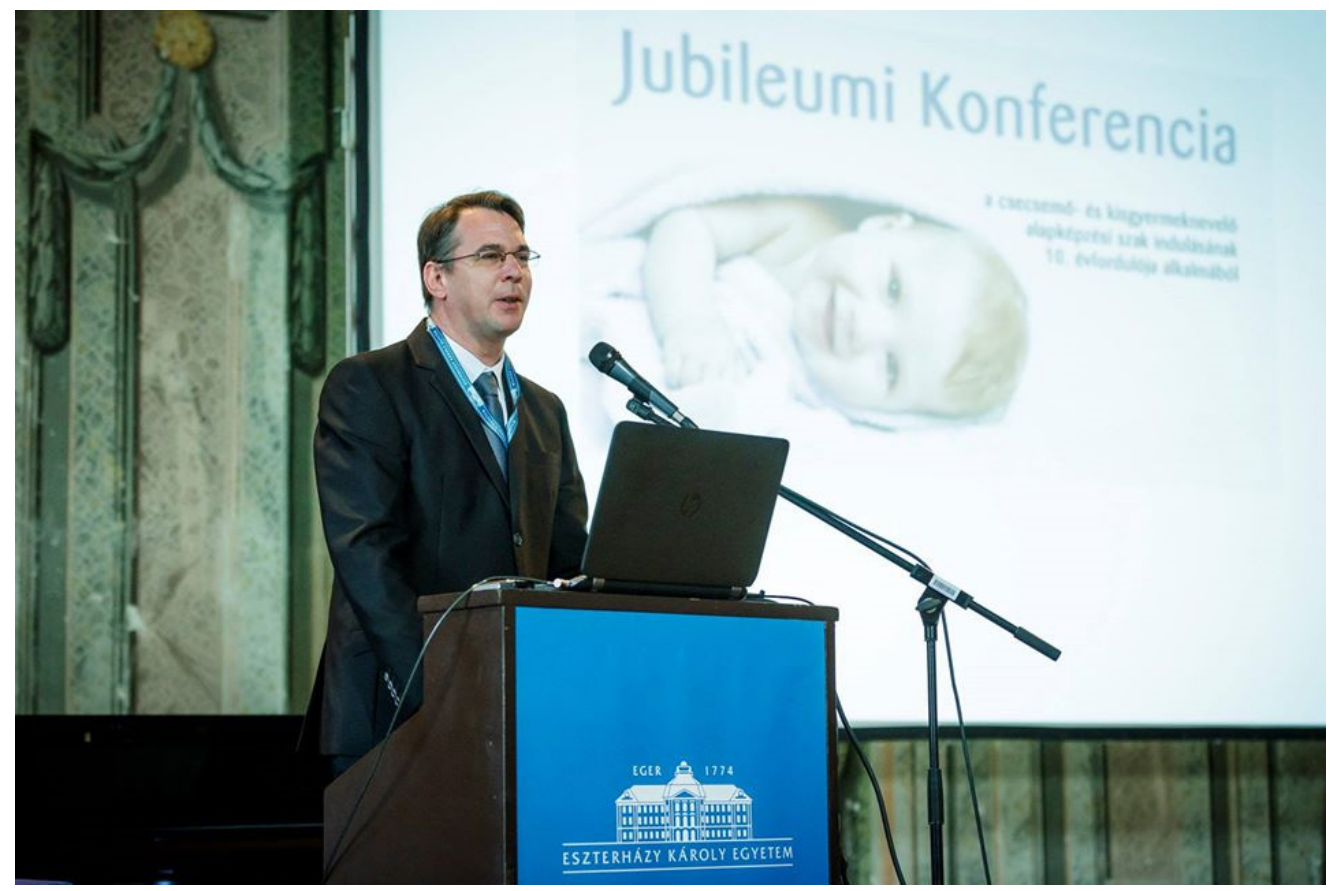

1. ábra: Mirkóczki Ádám, Eger város polgármestere a vendéglátó város nevében köszöntötte az egybegyűlteket 
A csecsemő- és kisgyermeknevelő ba-szak létesítésének előzményei...

A nyitó plenáris előadást prof. dr. Csépe Valéria tartotta, „A kora gyermekkori fejlődés - miért van szükség diplomás kisgyermeknevelőkre?" címmel. A kognitív idegtudománynyal foglalkozó pszichológus professzoraszszony előadásában rámutatott, hogy a korai gyermekkorban az ingergazdag környezetnek és a színvonalas nevelésnek, gondozásnak kiemelkedő jelentősége van, mert az idegrendszeri struktúrák kialakulását befolyásolja. Ezért fontos, hogy a legkisebb gyermekekkel foglalkozó szakemberek felsőfokú végzettséggel rendelkező pedagógusok legyenek.

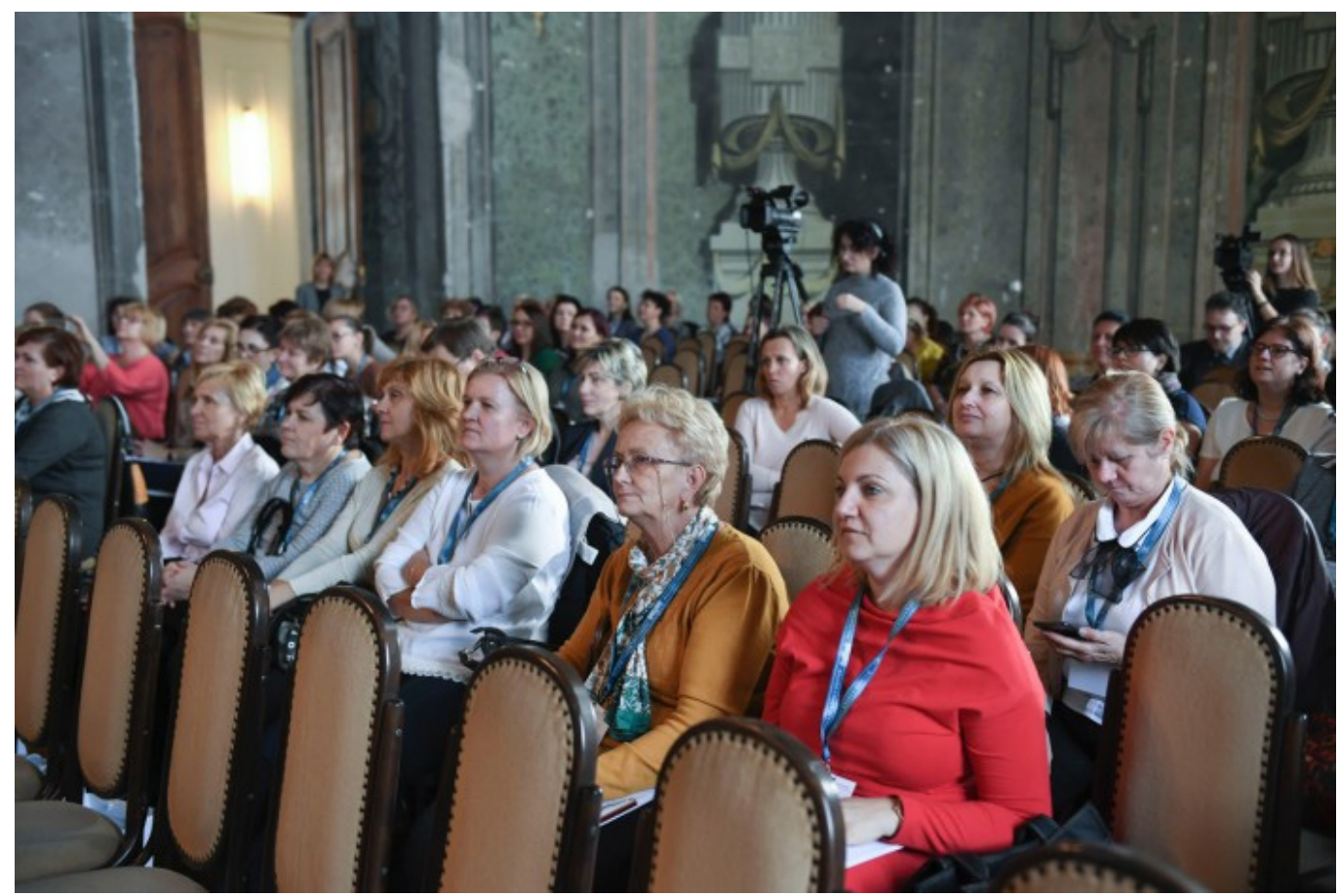

2. ábra: A plenáris előadás résztvevői

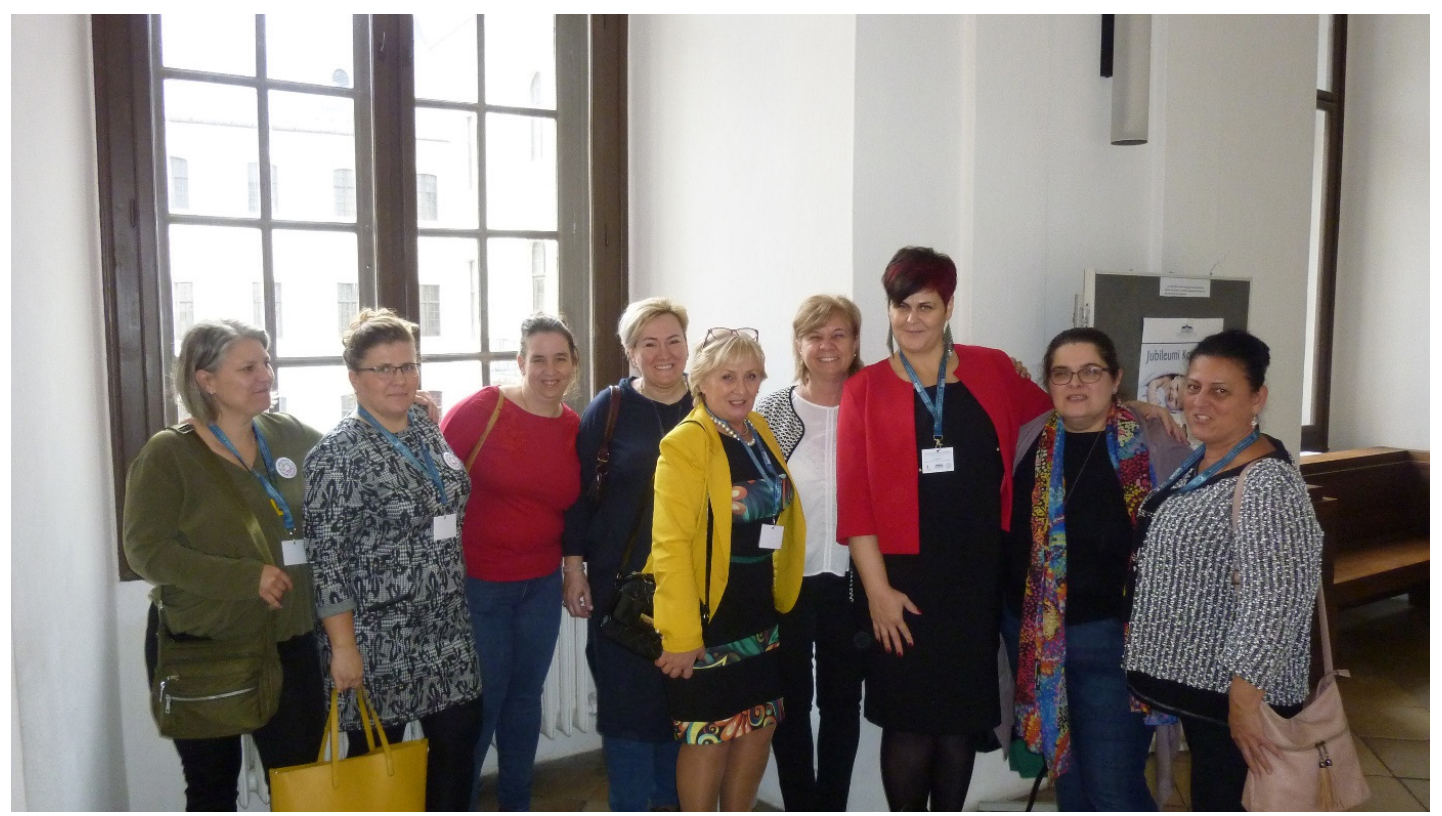

3. ábra: A poszterszkciót megtekintették az Egerben végzett első évfolyamok volt hallgatói is 
Hegedűsné Végvári Katalin, a Magyar Bölcsődék Egyesületének elnöke a csecsemő- és kisgyermeknevelö BA-szak a bölcsődei szakma életében betöltött jelentőségéről beszélt. Dávid Mária, Estefánné Varga Magdolna és Kovácsné Bárány Ildikó a szaklétesítés és szakindítás előzményeit és hátterét mutatták be. Podráczky Judit pedig a kisgyermeknevelő-képzés első 10 évének mérlegét vonta meg.

A plenáris előadások szünetében poszterszekcióban 9 felsőoktatási intézmény mutatta be a csecsemő- és kisgyermeknevelő képzésük specifikumait. A plenáris ülés második részében Kereki Judit a kora gyermekkori intervencióról tartott átfogó előadást. Nyitrai Ágnes a kisgyermeknevelési koncepciók változásáról és ezek szakemberképzésben történő megjelenéséről beszélt. Szurominé Balogh Mónika pedig azt mutatta be, hogy hogyan érvényesül a pedagógus életpályamodell a kisgyermeknevelő szakmában.

A plenáris előadásokat követően két szekcióban a legújabb kutatási eredményeiket mutathatták be a képző intézmények. A két szekcióban összesen hat előadás hangzott el.

A vendéglátók az Egyetem dísztermét, Kápolnáját, és a Varázstornyot idegenvezetés- sel egybekötve mutatták meg a konferencia résztvevőinek.

Az első napot záró esti fogadáson dékánhelyettesi köszöntés, az Egyetemi Színpad müsora és születésnapi torta tette ünnepélyessé a jubileumot.

A Jubileumi Konferencia második napján Eger város négy bölcsődéjében, 15-20 fős csoportokban történt intézménylátogatás, és közvetlen szakmai tapasztalatcsere.

A bölcsődelátogatást követően öt mühelyfoglalkozáson korszerű módszertani megközelítésekkel ismerkedhettek meg a résztvevők. Az interaktív műhelyek foglalkoztak az innovatív módszerekkel a kisgyermekkori anyanyelvi nevelés területén. Eszmét cseréltek a Gordon-módszer bölcsődei alkalmazásáról. Bemutatták a környezeti nevelés lehetőségeit a bölcsődében, beszélgettek a „Zöld bölcsőde programjáról”. Kicsi gyermekek részvételével lehetővé vált megfigyelni egy „Ringató” foglalkozást, és beszélgetni ennek módszertanáról. Bábszínészek közreműködésével bemutatásra került a csecsemőszínház nevelő hatása kisgyermekkorban.

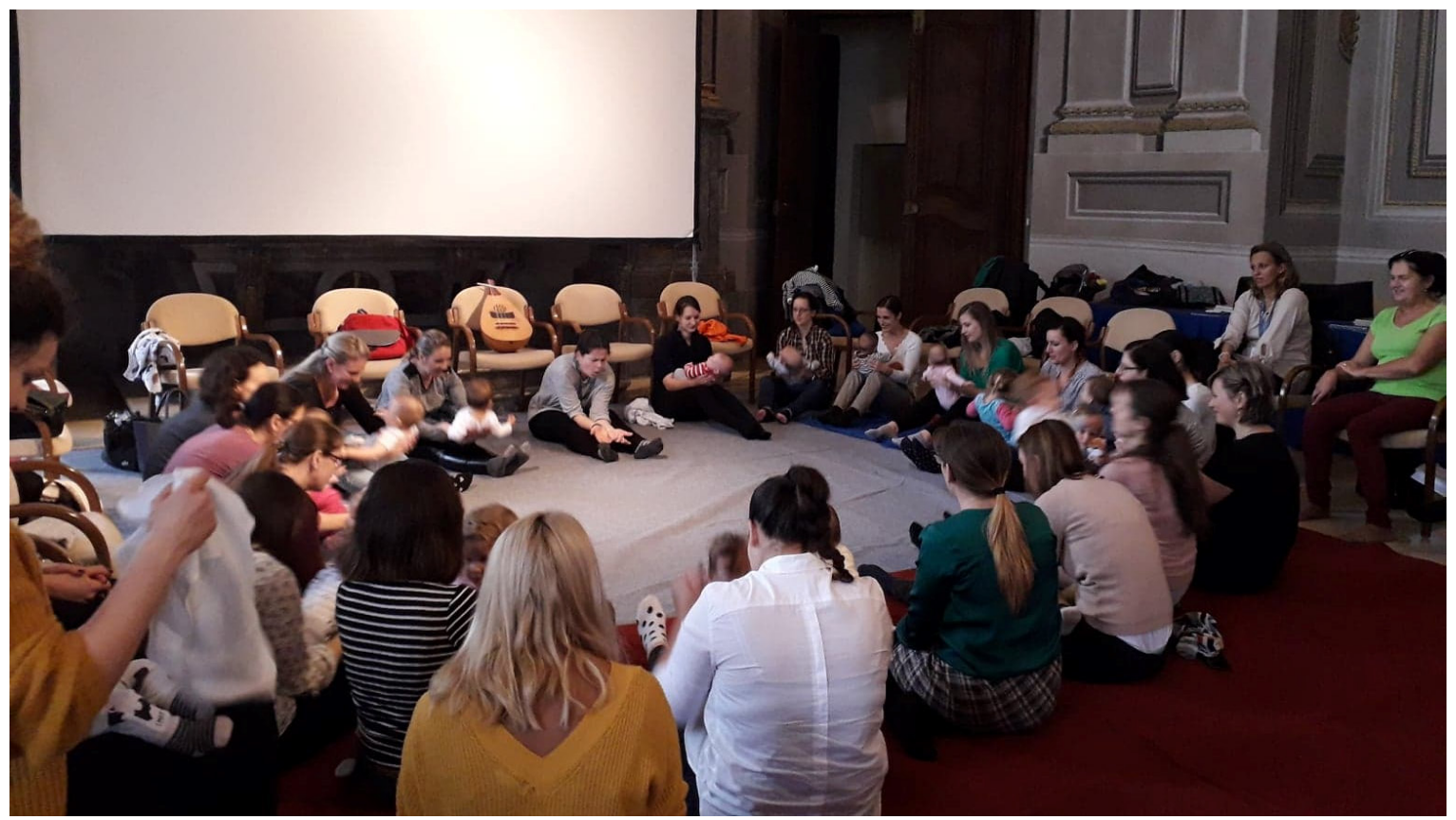

4. ábra: Műhelymunka - Ringató foglalkozás 
A csecsemő- és kisgyermeknevelő ba-szak létesítésének előzményei...

A konferenciát nagy érdeklődés kísérte, a regisztrált résztvevők létszáma közel 180 fő volt.

A plenáris előadásokat a Líceum televízió rögzítette, és az előadásokat tartalmazó videófelvételeket az alábbi linken meg lehet tekinteni: https://www.youtube.com/playlist?list= PLEcj-NxGCjMluJBl-8RVkYzA3XfWUNS8A

A rendezvényről beszámolt az Eger Televízió: http://www.tveger.hu/2019/11/14/10eves-a-csecsemo-es-kisgyer mekneveloszak/?fbclid=IwAR3m-XBh2IAG62xzP QnQdTw0qsuIowRQELEM3mTjo0iyoBqIYe7PR-4uHQ

\section{Felhasznált irodalom}

Blaskó Zsuzsa, Cseres-Gergely Zsombor, Reszkető Petra, Scharle Ágota és Váradi Balázs (2009): Az 1-3 éves gyermekek napközbeni ellátásának bövitése: költségvetési ráfordítás és várható társadalmi hatások. Budapest Szakpolitikai Elemző Intézet, Budapest.

Csecsemő és kisgyermeknevelö BA képzés Országos Programfejlesztő Bizottsága Küldetésnyilatkozata (2009): Kézirat. Budapest.

Derényi András (2010): A bolognai folyamat célkitüzéseinek magyarországi megvalósitása áttekintés. Bologna füzetek 5 . Tempus Közalapítvány, Budapest.

Jegyzökönyv a Magyar Rektori Konferencia Pedagógusképzési Bizottságának 2008. április 26-i üléséről, Eszterházy Károly Egyetem, Irattár, Eger.

Nyitrai Ágnes (2015): Pedagógiai szemléletmód a bölcsődei nevelésben-gondozásban. In: Podráczky Judit (2015, szerk.) Szemelvények a kisgyermeknevelés köréböl 1. Kaposvári Egyetem Pedagógiai Kar, Kaposvár, 35-55.

Petőné Csuka Ildikó (2016): „Emberitőke-elméletek oktatási kontextusban," Tanulmánykötet - Vállalkozásfejlesztés a XXI. században VI., Óbuda University, Keleti Faculty of Business and Management, 271-282.

URL: https://ideas.repec.org/h/pkk/vf2106/271282.html
Podráczky Judit (2015): A kisgyermeknevelés jelentősége, helyzete és perspektívái. In: Podráczky Judit szerk. (2015, szerk.) Szemelvények a kisgyermeknevelés köréből 1. Kaposvári Egyetem Pedagógiai Kar, Kaposvár, 57-82.

Kérelem, csecsemö- és kisgyermeknevelö alapszak létesitésére (2008): Eszterházy Károly Egyetem Irattár, Eger

Vokony Éva, (2002): Kis magyar bölcsődetörténet. Kapocs folyóirat, 1. 2. sz., 50-54.

7795-8/2005: Az Ifjúsági, Családügyi, Szociális és Esélyegyenlőségi Miniszter támogató levele Hauser Zoltánnak, az Eszterházy Károly Föiskola rektorának (2006), Eszterházy Károly Egyetem, Irattár, Eger

3204-2/2007.SZMM Szociális és Munkaügyi Minisztérium Szociálpolitikai Szakállamtitkára támogató levele Hauser Zoltánnak, az Eszterházy Károly Föiskola rektorának (2007), Eszterházy Károly Egyetem, Irattár, Eger

198/2007 RH Szociálpolitikai és Munkaügyi Intézet támogató nyilatkozatai Hauser Zoltánnak, az Eszterházy Károly Föiskola rektorának címezve. (2007), Eszterházy Károly Egyetem, Irattár, Eger

443/2007.TKTK: Az Eszterházy Károly Egyetem Tanárképzési és Tudástechnológiai Karának kérelme a Magyar Rektori Konferencia Pedagógusképzési Bizottságához (2007), Kézirat, Eszterházy Károly Egyetem, Irattár, Eger

4-4/2008. RH. Magyar Rektori Konferencia Pedagógusképzési Bizottsága levele a Magyar Rektori Konferencia elnökéhez (2008), Eszterházy Károly Egyetem, Irattár, Eger

2008/7/XII/3/1. számú MAB határozat (2008): A Magyar Felsőoktatási Akkreditációs Bizottság határozata a csecsemő- és kisgyermeknevelő alapképzési szak létesítéséről, Eszterházy Károly Egyetem Irattár, Eger

Interjú Dr. Hauser Zoltánnal, aki a szaklétesítés időszakában az Eszterházy Károly Főiskola rektora, és a Magyar Rektori Konferencia Pedagógusképzési Bizottságának elnöke volt.

Interjú Dr. Estefánné dr. Varga Magdolnával, aki a szaklétesítés időszakában az Eszterházy Károly Főiskola Tanárképzési és Tudástechnológiai Karának dékánja volt. 
The prework and background of creating the infant and early childhood education BA major programme

The infant and early childhood education training program has started in September 2009 for the first time, as a BA level major in the Hungarian higher education system. In this study, we review the professional merits of creating this training program. We present the process of development and approval of the training program document, and the national professional co-operation related to the start of this program.

Keywords: specialization, early childhood education, national co-operation 